\title{
The case for increased centralization in integration governance: the neglected perspective
}

Vilde Hernes(D

Correspondence: vildeher@oslomet. no

Norwegian Institute for Urban and Regional Research, Oslo Metropolitan University, Oslo, Norway

\begin{abstract}
Local autonomy is a highly promoted feature in European governance, and the integration field is no exception. In the integration literature, values and considerations favoring local autonomy are often emphasized, while values and considerations underpinning central steering has received less analytical attention, thus a more nuanced perspective in studies of central-local governance relations is warranted. This commentary identifies general dilemmas in central-local governance which expose clear justifications for both local autonomy and central steering. Furthermore, it presents empirical examples of policy changes regulating centrallocal governance in the Scandinavian countries where increased centralization has been introduced with reference to promoting values and considerations favoring central steering, such as a fairer distribution of responsibilities between local authorities, legal safeguards for individuals, and equal service provision across the country. Lastly, it suggests how future studies of central-local governance could benefit from of taking a more nuanced perspective.
\end{abstract}

Keywords: Central-local governance, Integration governance, Immigrant integration, Local autonomy

\section{Introduction}

"Local autonomy" is a highly valued and promoted feature in European governance, and many European countries continue to strengthen the autonomy of local governments by decentralizing far-reaching competences to the lowest units (Ladner et al., 2016). This promotion of local autonomy and decentralization is also apparent in the integration field, where both politicians and EU institutions enthusiastically praise the importance of a local approach to integration policies (Gebhardt, 2016). In recent years, the local governments' role in immigrant integration, and particularly the role of large cities, has also been extensively studied in the integration literature, where national policies involving increased centralization are often criticized, and where local autonomy is presented as a solution to ensure a holistic integration process responding to concrete problems (Poppelaars \& Scholten, 2008; Jørgensen, 2012; Dekker et al., 2015; Gebhardt, 2016).

(c) The Author(s). 2021 Open Access This article is licensed under a Creative Commons Attribution 4.0 International License, which permits use, sharing, adaptation, distribution and reproduction in any medium or format, as long as you give appropriate credit to the original author(s) and the source, provide a link to the Creative Commons licence, and indicate if changes were made. The images or other third party material in this article are included in the article's Creative Commons licence, unless indicated otherwise in a credit line to the material. If material is not included in the article's Creative Commons licence and your intended use is not permitted by statutory regulation or exceeds the permitted use, you will need to obtain permission directly from the copyright holder. To view a copy of this licence, visit http://creativecommons.org/licenses/by/4.0/. 
In this commentary, I argue why the integration literature should take a more nuanced perspective when studying the complexity of central-local governance relations. I start with a brief review of how central-local relations have been studied in the current integration literature, and argue that although it often describes in detail theoretical and empirical justifications for local autonomy, the same analytical attention is seldom given to justifications for central steering. By building on the general centrallocal governance literature, I therefore first present general dilemmas in central-local governance which expose clear justifications for both local autonomy and central steering. Further, I continue by showing concrete examples from analyses of refugee integration and settlement policies processes in the Scandinavian countries, where increased centralization has been introduced with reference to promoting values and considerations favoring central steering, such as macroeconomic considerations, legal safeguards for individuals, equal service provision across the country, and a fairer distribution of responsibilities between local authorities. In the concluding discussion, I review how insights from the Scandinavian examples presented may challenge an existing assumption in the literature, namely that increased centralization most often is a tool to introduce more restrictive integration policies. Furthermore, I discuss how the dominant analytical approach in the existing integration literature focusing mainly on large cities when studying central-local relations may present a skewed picture, and suggest that future studies should include analyses of local governments of varying sizes and with varying shares of an immigrant population to get a broader understanding of central-local governance relations within the integration field.

It is important to emphasize that this commentary is not meant as a general normative justification for increased centralization in the integration field. By highlighting that legitimate reasons for central steering exist - reasons that have not been sufficiently exposed in the current integration literature - my aim is to provide future empirical analyses with a broader understanding of the complexity that dilemmas of central-local governance in the integration field entail.

\section{Central-local governance in the integration literature}

The literature on central-local governance integration has mainly included studies that analyze how local governments - and particularly large cities - develop their own integration policies. Scholars studying the "local turn" show that local governments are not merely implementers of national integration policies, but increasingly formulate their own integration policies that may diverge from the "national models of integration" (Alexander, 2003; Jørgensen, 2014; Ambrosini \& Boccagni, 2015; Dekker et al., 2015; De Graauw \& Vermeulen, 2016; Emilsson, 2016; Penninx et al., 2017). Furthermore, Zapata-Barrero et al. (2017) find that conflicting policies at the national and local levels may lead to inconsistencies among the policies pursued by different levels of government. Schiller et al. (2020) also show that national and local actors' perceptions of immigration, diversity and their societal consequences have undergone important transformations in the past two decades.

In contrast to the "local turn" thesis, other studies show how national policies infringe on the local leeway to adopt integration policies in line with local policy objectives and local philosophies of integration (Emilsson, 2015; Gebhardt, 2016). Thus, the idea that local governments enjoy a high degree of autonomy from the state has been 
challenged. Emilsson (2015) shows how the central government can exercise power over local governments in his studies of how national governments use different instruments (coercive, remunerative, and normative) in their national integration policies to regulate the local leeway. By taking this approach, he finds what he calls a "national turn" in Swedish and Danish integration policies. Gebhardt (2016) takes a similar approach and shows how state-led civic integration programs across Europe challenge a local approach to integration.

Generally, integration scholars present thorough arguments portraying the benefits of local autonomy; however, justifications for introducing (increased) central steering have received less analytical attention. Some studies briefly mention geographical fragmentation and variation, unsatisfactory integration results, and standardization as reasons for why national governments have taken centralizing steps (Dekker et al., 2015; Emilsson, 2015; Gebhardt, 2016); however, they do not describe or discuss different reasons for central steering, at least not to the same extent as is done for the justifications for local autonomy. Studies on multi-level governance of the integration field, and particularly studies of central-local governance, have also mainly been descriptive, and few studies explore in-depth the reason why we see these patterns of both centralization and decentralization (Gebhardt, 2016; Zapata-Barrero et al., 2017). Trends of centralization are therefore often assumed to be a result of the central government having discovered integration policies as a potential "tool to regulate and condition immigrant rights, and as a resource for symbolic politics in a context of a marked politization of immigration" (Gebhardt, 2016). Although this assumption might be right for some centralizing developments in certain countries, integration scholars should investigate not only this hypothesis, but also competing hypotheses for why we see increased centralization of integration policies in many countries.

In conducting such investigations, we should acknowledge that in choosing between local autonomy and central steering, multiple and often conflicting values and considerations must be prioritized and balanced, and that explanations for trends of decentralization or centralization are equally complex and multifaceted. To explore and systemize this complexity, a starting point is to clarify the different values and considerations both local autonomy and central steering represent.

\section{Local autonomy versus central steering - a balancing act between different considerations and values}

Several scholars have argued that integration scholars could benefit from employing tested frameworks and theories from the public policy and administration literature (Bleich, 2008; Filindra \& Goodman, 2019). While integration scholars increasingly have devoted more time on studying central-local governance, there is unexploited potential to build on established insights from the general central-local governance literature in analyses of integration governance. In the following section, I describe the general considerations underpinning both local autonomy and central steering presented in the general central-local governance literature.

\section{Values and considerations favoring local autonomy}

The ideological justification for self-governance rests on three sets of values or ideals: 1) democracy and participation, 2) liberty or autonomy, and 3) efficiency (Kjellberg, 1995). 
First, the democratic justification for local autonomy is that citizens' participation in local democracy is viewed as both a goal in itself and an instrument for strengthening democracy in society at large. The justification emphasizes the importance of proximity between citizens and elected politicians, because it narrows the gap between rulers and the ruled (Kjellberg, 1995).

Second, for the democratic justification to be relevant, local governments must enjoy some degree of authority and self-governance, implying liberty from the central government's direct steering. Liberty for local communities to develop according to their own preferences was a powerful ideological element in the introduction of local governments in European countries (Kjellberg, 1995). Liberty or autonomy is both a question of 'freedom from' and 'freedom to'. 'Freedom from' central steering is related to the local governments' role as implementers of national policies and implies that local governments should have the leeway to adapt national legislation to local conditions without detailed directions from the central government. "Freedom to" relates to the local leeway to initiate and develop new policies and programs that are not explicitly under the authority of higher government levels (Ladner et al., 2019).

The third value and justification for local autonomy is that local governments may offer the most efficient way of handling the discrepancy between needs and demands in the community, as well as efficiently adapting the local production of public services (Kjellberg, 1995). With knowledge of local needs and conditions, and with proximity between citizens and politicians, local governments may be more capable of implementing policies effectively and to develop, prioritize, and adapt public services to their citizens' needs (NOU, 2005:6).

\section{Values and considerations favoring central steering}

While the three abovementioned ideals provide a good case for local autonomy as a highly desirable feature for "good" governance (Ladner et al., 2019), in developed welfare states, these ideals compete with other values rooted in national considerations (Kjellberg, 1995). Considerations that may favor central steering are 1) the rule of law and legal safeguards for individuals, 2) equal service provision, 3) efficiency, and 4) macroeconomic steering.

First, a strong central power is viewed as a precondition to ensuring the rule of law and legal safeguards of individuals, where central intervention may be necessary to ensure that civic rights are free from encroachment by local authorities (Kjellberg, 1995). Historically, as evolving democratic communities, local governments have been viewed as defenders of individuals and groups against central government intrusions. However, in modern welfare states, municipalities are also implementers of national welfare policies, and thus, the roles may be reversed where legal safeguards for individuals or groups may be upheld by the central government, not the local government. One example concerns how municipalities work to ensure that persons with disabilities overcome barriers and are included in society. A Norwegian Green paper (NOU, 2001:22) problematized that through a too strong focus on local autonomy, the extent of variation of the public services provided to persons with disabilities in different municipalities infringed citizens' legal safeguards and contradicted the goal of equal service provision. Thus, increased central steering and control could be a way to ensure that 
individuals get what they are entitled to, irrespective of where they live in the country. Consequently, this first value of legal safeguards is intertwined with the second justification for central steering: equal service provision. Although local adaption may be promoted as a desirable feature favoring local autonomy, it could also result in arbitrary differentiation in service provision across the country. European welfare states are built upon principles of universalism and egalitarianism (Sellers \& Lidström, 2007). Hanssen and Helgesen (2011, b) present two prerequisites for universalism: universal accessibility and coverage, and territorial uniformity. Universal accessibility and coverage implies that everyone with equal needs should have equal access to services across all municipalities in the country. Who you are and where you live should not affect services provided to cover your needs. Territorial uniformity implies a specified level of service quality across all municipalities. Since decentralization and local autonomy promote local variation, it may be hard to reconcile with the principle of universalism; thus, ensuring universalism may require a certain level of national regulation and central steering (Hanssen \& Helgesen, 2011, b). The argument about equalization and a demand for redistribution in society (Kjellberg, 1995) also entails equality between local governments. In this way, central steering could be a way to (re) distribute resources and responsibilities among local governments when such redistribution does not happen through voluntary local engagement (NOU, 2005:6). In such cases, central steering may delimit local autonomy for some local governments, while others gain increased selfgovernance through central steering.

Third, central steering may also be justified by its functioning as a measure to ensure efficient implementation of national policies. This argument stands in contrast to the efficiency argument for local autonomy, and the two forms of efficiency may be perceived to be in conflict. While the efficiency argument for local autonomy emphasizes an optimal correlation between specific local needs and the supply of services, it may not always be the cheapest solution. Public money is not to be wasted (Kjellberg, 1995). Because local governments often are financially compensated (or at least should be) for tasks they are mandated to carry out by the national government as implementers of national policies, it is legitimate for the central government to ensure that public service production is as efficient as possible (Kjellberg, 1995).

This latter point brings us to the fourth central consideration, macroeconomic steering. Local governments with wide responsibilities as implementers of several welfare services are responsible for a large part of the national budget. Additionally, their success or failure in the implementation process may have a large impact on the achievement of national policy goals. Thus, if local governments consistently fail to reach the goals set by the national government, that failure could have severe macroeconomic consequences, and therefore alternative solutions, including increased centralized steering and control, might have to be considered.

\section{Analytical approach}

As presented above, both local autonomy and central steering promote different considerations and values in public governance. The current integration literature has extensively studied how trends of increased centralization in integration policies may infringe important values of local autonomy. However, the literature has not always devoted the same attention to portraying how increased centralization might have been 
introduced to protect values of central steering. The importance of the conflicting values of local autonomy and central steering has fluctuated over the years; nevertheless, as Kjellberg argues, the values for central steering cannot be " (...) discarded as irrelevant or as being less important than the values imbued in local self-government itself. They all contribute to the legitimacy of the political system" (Kjellberg, 1995). Thus, in the next section, I present concrete examples of policy processes where increased centralization has been introduced in the integration field. I document how these centralizing trends have been justified by relevant actors because of their function as a measure to ensure and protect central values of legal safeguards, equalization, efficiency, and macroeconomic steering.

The examples are drawn from existing policy studies and new analyses of more recent policy processes regulating Scandinavian integration programs and settlement policies for refugees, because these policy issues tackle core dilemmas of central-local governance. I use examples from Norway, Denmark, and Sweden because they all have extensive welfare states and decentralized government structures, and in all three countries, local autonomy has a particularly strong standing in central-local governance relations (Sellers \& Lidström, 2007). Thus, in those countries, increased centralization may face stronger opposition, and should be thoroughly and explicitly justified in the policy process. Despite these similarities, the countries have approached immigrant integration quite differently. In all indices of integration policies, Denmark is placed in the restrictive corner, Sweden in the permissive one, and Norway somewhere between (Hernes, 2018; Goodman, 2010). This makes them relevant cases to see how centrallocal governance relations are addressed in countries that historically have had very different national approaches to integration policies. The empirical examples used here are not meant as a thorough analysis of all possible explanations or main drivers of the respective policy changes, but rather, they are meant to exemplify how values underpinning central steering are explicitly highlighted by relevant actors to justify increased centralization.

\section{Justifications for centralization in integration programs and settlement policies for refugees}

Ensuring equal service provision and legal safeguards in integration programs

The Scandinavian central governments' leeway for central steering of municipalities is somewhat restricted by the principle of proportionality. The principle states that policies that restrict local autonomy should be applied only if they are necessary to fulfill important national goals and that the least restrictive instruments should be preferred (Feltenius, 2015). However, in both Norway and Sweden, there has been a consistent employment gap between refugees and the majority population (Bratsberg et al., 2017, Hernes et al., 2020). In the Scandinavian countries, high employment levels are a precondition for the central government to finance and maintain an extensive welfare state. A continuous employment gap between the minority and majority population has negative consequences for state finances, and for other goals of maintaining social and financial equality in the population (NOU, 2017: 2). Thus, from a macroeconomic perspective, if local integration measures do not achieve results that are vital for individual migrants, local communities, and more holistic national goals and state finances, the 
national government may want to become more involved. Both Norway and Sweden have introduced centralizing instruments or centralized the responsibility for implementing integration programs for refugees in recent years, and increased employment and self-sufficiency for the target group have been the main aims of these efforts. However, the policy processes leading up to these changes also show that equal service provision and legal safeguards for refugees are emphasized as important justifications for these policy and organizational changes.

In Norway, the Introduction Act of 2003 gave municipalities the responsibility to provide integration programs for refugees (financed by the central government). The Act gave municipalities great autonomy in designing and locally adapting the program conditions, with few detailed regulations. Over the years, several evaluations have revealed large differences between both the results municipalities achieve concerning participants' transition rate to employment after the program period, and the quality of the content of integration programs (Djuve et al., 2017, Riksrevisjonen, 2019). For example, while some municipalities had transition rates to employment up to $100 \%$, other municipalities achieved only about 30-40\% (Lillegård \& Seiersted, 2013). Nilsen (2013) also problematizes the emphasis on local autonomy, because it provides local case workers with great power when deciding the program content for each individual. In her analysis of the legal safeguards for participants in the Norwegian integration programs, Nilsen writes that refugees' legal safeguards are ensured through the legislation, which emphasizes the principle of user participation and the right to appeal the formal decision (e.g., which measures individuals should have in the program, e.g., employment or educational measures). She shows that there are very few cases of appeals, and that central inspection of the programs' contents shows that several municipalities struggle to provide participants with fulltime programs. Consequently, even though participants formally have a legal safeguard in their right to appeal formal decisions, Nilsen (2013) emphasizes that participants are new to Norway, and often lack the knowledge and resources to understand the Norwegian system, making it more challenging for them to execute their right to appeal public decisions. Thus, she argues that national legislation (and inspection) could protect refugees' rights (e.g., by more centralized steering of the program content to ensure minimum standards for the programs' content and quality). From this perspective, stronger central steering could be justified as an argument to ensure refugees' rights, and to provide a more equal service provision to refugees, irrespective of where they are settled in the country. If the program quality in some municipalities is particularly low, it is a severe intervention in participants' lives because they are obliged to participate in the programs and could be refused financial aid if they do not participate (Tronstad \& Hernes, 2017).

In October 2020, the Norwegian parliament passed a new Integration Act replacing the former 2003 Introduction Act. As a backdrop to the new legislation, the government's proposition to parliament stresses that: "There is large municipal variation concerning the program content, quality and results in the integration programs ( ...)" (Kunnskapsdepartementet, 2020: 15). They quote an evaluation report of the 2003 act (Djuve et al., 2017), which concludes that although many municipalities do find suitable local solutions for the integration process, (...) "the local variations in program measures are disturbingly large, and affect the individual participants' chances to become employed." One major change in the new Integration Act is a more detailed steering of 
the program content, with clear requirements concerning what specific measures municipalities are to include in different participant groups' programs. Additionally, the new Act introduced a quality requirement (forsvarligehtskrav) for municipalities, meaning that the program should meet certain quality standards. In the public hearing, this latter requirement was both supported and opposed, but the main argument from supporters and eventually the government was that it would "reduce differences between municipalities and secure better services for participants" (Prop. 89 L (2019-2020), p. 41). Although the public consultation reveals that several municipal actors were critical of the Act's proposals for increased detailed central steering, many municipal actors also supported these proposals, with the same justification as presented by the central government: that it could lead to a more equal service provision and increase participants' rights. As Grong municipality writes in the public hearing: "the development towards more formalization and systematization may promote equal service provision and clearer steering and guidance for the municipalities in the development of the service provision for refugees" (Prop. 89 L (2019-2020), p. 38).

Similar arguments of equal service provision and legal safeguards were also prominent in the Swedish Establishment Act centralizing the responsibility for integration programs in 2010. Sweden took the first steps toward an integration program for refugees in 1994, whereby municipalities were given a fixed grant for each participating refugee. The legislation provided municipalities with great autonomy because the only requirement to receive this benefit was that the municipality - in cooperation with the participant - should prepare an individual integration plan. Municipalities could also choose the type of financial support they wanted to provide to program participants and if they wanted to include financial sanctions in case of non-participation. Consequently, program quality and benefit levels varied across Sweden, because municipalities were free to pay participants either an introduction benefit or social assistance (based on household income) (Andersson Joona et al., 2016). Most importantly, it was voluntary not only for refugees to participate, but also for the municipalities to offer such programs. National guidelines were few and vague, providing municipalities with great autonomy, but simultaneously resulting in wide variation across municipalities. Furthermore, studies revealed that few municipalities actually implemented these voluntary measures (Borevi, 2010).

The Swedish Establishment Act of 2010 centralized the overall responsibility for integration programs from the municipalities to a national agency, the Swedish Public Employment Service, including responsibility for work-related schemes and coordinating involved actors. The Swedish municipalities kept their responsibility to provide language training and civic studies. One of the main arguments for centralizing the responsibility was not only to facilitate and speed up integration into the labor market and society, but also to reduce the local variation of integration measures available, because the differences in how municipalities organized the programs were too great (Emilsson, 2015, Andersson Joona et al., 2016). In the political process, differences in how the municipalities chose to financially compensate participants and differences in whether participants were financially sanctioned for non-participation or not were highlighted because such differences challenged the principle of equal rights for the target group.

Territorial equalization is an important principle in welfare states (Hanssen \& Helgesen, 2011, b), and the examples above show how Swedish and Norwegian actors justify 
increased centralization of integration programs to promote principles of equal service provision and legal safeguards for program participants. The principles of equal service provision and legal safeguards could be argued to be particularly relevant for refugees, because in many countries (including Norway), refugees do not decide where to live themselves, but are settled by public authorities, and are restricted from moving the initial years after settlement (Hernes, 2017). Additionally, participation in integration programs is obligatory in many countries, implying that refugees are obliged to participate in the program to receive financial assistance, and in some countries, participation in the integration program may be a (indirect) precondition for obtaining permanent residence (Gebhardt, 2016). Thus, the quality and content of the integration programs, and the integration results participants achieve after the program period, have direct and severe consequences for participants. If the quality of the programs is low, it is a severe interference and restriction for the individuals that are obliged to participate (Hagelund \& Kavli, 2009).

\section{Increased centralization in refugee settlement policies}

The argument concerning equalization as an important principle in welfare states could also entail the goal of equal distribution of responsibilities between municipalities. Normally in discussions of central-local governance, this consideration concerns questions of redistributing resources between wealthy and less wealthy municipalities. However, this argument for equal distribution of responsibilities between municipalities has also been highly relevant for increased centralization of the Danish and Swedish settlement models. In these cases, the question is not about a distribution of resources, but rather about a redistribution of responsibilities for newly arrived refugees among the municipalities. In an in-depth analysis of several policy processes leading to increased centralization in Scandinavian settlement models, Hernes, (2017) shows that the Danish and Swedish steps toward centralized settlement models - whereby a central agency allocates refugees to the municipalities - were argued to be necessary to ensure that all municipalities took their share of the responsibility for newly arrived refugees, and to unburden municipalities that had taken disproportionately large shares in the years leading up to the new legislative changes. Municipalities that had taken a larger share than others actively supported the introduction of central steering to ensure a fairer distribution of responsibilities between municipalities.

In her analysis, Hernes (2017) also shows how Norway did not introduce a centralized settlement model, partly explained by how local autonomy has a particularly strong political standing in Norway. However, the analysis of the policy processes leading up to a decline of increased centralization illustrates how increased centralization may be promoted by different actors with the aim of protecting immigrants against negative consequences of too much emphasis on local autonomy. The Norwegian refugee settlement model has, despite several attempts of increased centralization over the years, kept the main principle of local autonomy, implying that the central government sends a petition each year to municipalities requesting that they settle a number of refugees that have been granted asylum and received a residence permit. Municipalities are free to accept the requested number of refugees, accept a lower number, or refuse to settle any at all (and they could even not answer the petition). Because accepting to 
settle refugee involves obligations for municipalities to provide refugees with housing and extensive integration programs the initial years, the main argument for this voluntary municipal model is that municipalities are the ones best suited to evaluate how many refugees they have the capacity to receive. However, before the refugee crisis in 2015, Norway experienced a substantial gap between how many refugees had obtained a residence permit and how many the municipalities accepted to settle, implying that many refugees that had their asylum applications approved sat waiting for months in asylum centers even after they obtained a residence permit (Askim \& Hernes, 2017). In a public hearing of a proposition that suggested to introduce central allocation in 2011, all ten organizations working for refugees' rights supported central allocation. Although many of them emphasized local autonomy as an important principle, they argued that local autonomy should not be kept as a principle if it delayed the refugees' rights to start their new lives in a municipality. The organization the Norwegian Centre Against Racism (2011) argued in their response in the public hearing that:

(... it is a form of coercion irrespective of which [settlement] model one chooses, irrespective of whether it is the municipalities that are forced to settle more refugees, or if the refugees are forced to live even longer in asylum reception centers. We consider it far more preferable for the system to be forced to deal with the problem, rather than for the consequences of the system's failure to affect individuals who already have a very difficult background.

This response shows how increased centralization could be argued as a measure to protect refugees' rights against negative consequences that may follow from a strong focus on local autonomy.

\section{Concluding discussion}

The examples presented in the previous section illustrate cases of increased centralization within the integration field, where changes have been justified by referring to values and considerations underpinning central steering, including macroeconomic steering, and by referring to the need to ensure the immigrants' legal safeguards against either unsatisfying or unequal local service provision.

It is relevant to highlight that these centralizing steps have in many cases been partly supported by municipalities themselves and by organizations working for immigrants' rights. The existing narrative in the integration literature often leaves the impression that the central state is the restrictive actor that limits or conditions immigrants' rights and that centralizes integration policies without much consultation with municipalities (Gebhardt, 2016). However, the examples in this commentary illustrate how the central government could also have an alternative role as an advocate to ensure equal distribution of responsibilities between municipalities, and equal rights and minimum standards of local service provision for immigrants, and that these centralizing steps have the support of immigrant organizations and even parts of the municipal community.

One limitation with the presented empirical examples in this study is that they only represent policies for refugee integration programs and settlement policies. Whether similar observations are apparent for integration policies aimed at other groups of migrants is an open question and should be further explored. For example, one could 
assume that refugees' more vulnerable position - often not being able to move back to their home country, other countries or in some cases not even freely settle within the host country - makes policies directed at refugees more subject to central interference where actors justify centralization steps to sustain this vulnerable groups' legal safeguards. Additionally, the empirical examples in this commentary is based on Scandinavian integration policies. These countries' different approaches to national integration policies make it possible to hypothesize that the similar justifications for increased centralizations may also be used in other countries with both restrictive and permissive integration policies, however, this hypothesis should naturally also be tested in future research.

\section{Implications for future research on central local governance}

How do these findings correspond to conclusions in existing studies of the centrallocal governance relations, and what lessons may be learned for future studies?

First, the Scandinavian examples presented could challenge or nuance an existing assumption in the integration literature, namely that patterns of centralization and the introduction of (more) coercive and restrictive policies for immigrants automatically go hand in hand. For example, in Gebhardt's study of the increased centralization of civic integration programs in Sweden, Netherlands, and Germany, he concludes that:

Civic integration programs are part of a wider trend that has seen immigrant integration policy redefined by a growing involvement of the state. Although this has often meant that more resources have been made available for integration, it has also resulted, albeit to a lesser degree in the Swedish case, in making integration policies more coercive, more linked to questions of admission and residence status, more bureaucratic and less concerned with solving practical problems or responding to concrete needs (Gebhardt, 2016).

He further writes that it can be assumed that this centralizing trend has:

to do with integration policies having been discovered by governments as a tool to regulate and condition immigrant rights, and as a resource for symbolic politics in a context of a marked politicization of immigration. The fact that this [national] understanding of integration can clash with a local understanding of integration that is more oriented to solving concrete problems may make central governments inclined to take greater control and to ignore the good governance rhetoric of "bottom-up policy development" and "partnership" (...) (Gebhardt, 2016).

One important takeaway from this commentary is that increased central steering of local governments may be detached from the introduction of more restrictive and obligatory integration policies for immigrants. The policy changes made by the Swedish Establishment Act in 2010, the more centralized Swedish settlement model, and the new Norwegian Integration Act do not impose new obligations for immigrants, but either centralize authority over integration policies or increase the central steering of the local service provision. The examples show that centralization may be introduced not with the intention of imposing further restrictions on or obligations for immigrants, 
but rather as measures to improve immigrants' rights and ensure equal service provision across local governments. Of course, these examples do not mean that earlier studies are wrong in their conclusions that centralization and the more obligatory and restrictive policies toward immigrants often go hand in hand; however, the examples show that this does not always have to be the case. Changes in the governance of integration policies may "merely" be political questions of balancing or prioritizing between conflicting values and considerations of central-local governance. Thus, future studies that aim to address the central-local governance relations must distinguish analytically between cases where centralization is part of policy changes that also impose new restrictions on immigrants and policy changes that "just" regulate the central-local governance of integration policies. This distinction is particularly relevant in studies that aim to investigate why we see increased centralization. In many cases, it may be as Gebhardt (2016) concludes, that centralization is a measure to introduce the more obligatory and restrictive policies to ensure immigration control. Nevertheless, as shown in this article, it may also be justified by values and considerations in support of central steering - such as legal safeguards and equal service provision - two highly valued features in European welfare states (Ladner et al., 2019). This approach is a supplement to Ambrosini (2013) critique of how most of the literature focusing on local government deals with the inclusive role of local policies. As Ambrosini argues - and other studies have also shown (Mahnig, 2004, Scholten, 2013) - there are cases where the development of local policies have been aimed to exclude migrants from various kinds of benefits and rights. Similarly, just as these studies challenge the general assumption that integration policies necessarily do not have to be inclusive, the Scandinavian cases illustrate that increased central steering may not necessarily imply the introduction of more restrictive integration policies.

A second and methodological implication of my argument to take a more nuanced approach to study of central-local governance relations, is that the dominant approach of studying big cities with large immigrant populations may give a skewed picture of the overall local capacity and competency to independently develop and implement integration policies. Earlier studies of the "local turn" have shown how big cities have been forerunners in developing extensive local integration policies and adapting integration measures to local needs (Poppelaars \& Scholten, 2008, Jørgensen, 2012, Dekker et al., 2015). Glick-Schiller and Çağlar (2009) criticize that studies of specific localities (e.g. metropolitan cities) are used to draw general more conclusions about a countries' integration policies, and argue that future studies should include localities that differ not only in size, but in their social, cultural and political dynamic. Current studies of central-local governance often show innovative and knowledgeable big cities that have great experience and capacity in developing and implementing local integration policies. Nevertheless, these studies are almost exclusively based on case studies of big cities. Although immigrants are often overrepresented in urban areas, most European countries have immigrant populations distributed across the country, in municipalities of all sizes. To develop extensive integration programs and policies, local governments need resources, capacity, and knowledge. Such programs and policies could be challenging to develop from scratch, particularly for smaller municipalities with fewer resources and less experience with an immigrant population. De Graauw and Vermeulen (2016) argue that local-level factors such as having a sizeable share of immigrants and 
their direct descendants as part of the electorate, and an infrastructure of communitybased organizations that actively represent immigrants' collective interests in local politics and policy-making are critical for the enactment and implementation of local integration policies. Thus, although earlier studies have shown certain negative side effects of national policies limiting the local autonomy in big cities, future studies should include studies on how such trends of centralization have affected the content and implementation of integration policies in municipalities of different sizes and with varying shares of immigrant populations. For example, for smaller municipalities with limited resources and experience with this type of work, detailed regulations of the integration programs' content may be welcomed so that all municipalities do not need to reinvent the wheel all by themselves (Tronstad \& Hernes, 2017). Additionally, smaller and rural municipalities may have different attitudes and incentives towards centrally steered integration (and immigration) policies than big cities have, since nationally financed integration policies implemented by the local level may have positive effects on local budgets, and that settlement of refugees could reverse a continuing trend of population decline (Hansen, 2018, Scarpa \& Schierup, 2018).

Lastly, I want to emphasize again that this commentary is not meant as a normative justification for increased centralization in the integration field, but rather as a call for a more nuanced analytical approach when studying trends of both decentralization and centralization in the integration literature. While the current literature has shown many good examples of the importance in local leeway and discretion in the formulation and implementation of integration policies, my goal with this commentary has been to nuance this picture by also elaborating and exemplifying how increased centralization have been justified by referring to values and considerations underpinning central steering. To repeat Kjellberg (1995), the values for central steering cannot be “( ...) discarded as irrelevant or as being less important than the values imbued in local selfgovernment itself. They all contribute to the legitimacy of the political system."

Acknowledgements

I wish to thank the four anonymous reviewers for their constructive comments. I also want to thank Anne Balke Staver, Kristian Tronstad, and participants at NORKOM 2020 and the Network for Migration and Transnationality at OsloMet for comments on earlier drafts.

Author's contributions

The authors read and approved the final manuscript.

Author's information

Vilde Hernes is a senior researcher and political scientist at the Norwegian Institute for Urban and Regional

Research, Oslo Metropolitan University. Her research and teaching cover public policy and design, central-local govern-

ance, organizational theory and immigrant integration policies and governance.

Funding

The project has not received external funding.

Availability of data and materials

Not applicable.

\section{Declarations}

Ethics approval and consent to participate

Not applicable.

Consent for publication

Not applicable. 


\section{Competing interests}

The author declares that she has no competing interests.

Received: 18 December 2020 Accepted: 11 June 2021

Published online: 03 September 2021

\section{References}

Alexander, M. (2003). Local policies toward migrants as an expression of host-stranger relations: A proposed typology. Journal of Ethnic and Migration Studies, 29(3), 411-430. https://doi.org/10.1080/13691830305610.

Ambrosini, M. (2013). We are against a multi-ethnic society': Policies of exclusion at the urban level in Italy. Ethnic and Racial Studies, 36(1), 136-155.

Ambrosini, M., \& Boccagni, P. (2015). Urban multiculturalism beyond the 'backlash': New discourses and different practices in immigrant policies across European cities. Journal of Intercultural Studies, 36(1), 35-53. https://doi.org/10.1080/07256868.2 014.990362.

Andersson Joona, P., Lanninger, A. W., \& Sundström, M. (2016). Reforming the integration of refugees: The Swedish experience. IZA Discussion Papers (IZA DP no. 103070).

Askim, J., \& Hernes, V. (2017). Bosetting av flyktninger: Hvem bør få siste ord, kommunene, staten eller flyktningen selv? In J. Askim, K. Kolltveit, \& P. G. Røe (Eds.), Smartere styring. Universitetsforlaget.

Bleich, E. (2008). Immigration and integration studies in Western Europe and the United States: The road less traveled and a path ahead. World Politics, 60(3), 509-538. https://doi.org/10.1017/S0043887100009072.

Borevi, K. (2010). Sverige: Mångkulturalismens flaggskip i Norden. In G. Brochmann, \& A. Hagelund (Eds.), Velferdens grenser. Universitetsforlaget

Bratsberg, B., Raaum, O., \& Røed, K. (2017). Immigrant labor market integration across admission classes. Nordic Economic Policy Review, TemaNord, 2017, 520.

De Graauw, E., \& Vermeulen, F. (2016). Cities and the politics of immigrant integration: A comparison of Berlin, Amsterdam, new York City, and San Francisco. Journal of Ethnic and Migration Studies, 42(6), 989-1012. https://doi.org/10.1080/13691 83X.2015.1126089.

Dekker, R., Emilsson, H., Krieger, B., \& Scholten, P. (2015). A local dimension of integration policies? A comparative study of Berlin, Malmö, and Rotterdam. International Migration Review, 49(3), 633-658. https://doi.org/10.1111/imre.12133.

Djuve, A. B., Kavli, H. C., Sterri, E. B., \& Bråten, B. (2017). Introduksjonsprogram og norskopplæring. Hva virker for hvem? Faforeport, 2017, 31.

Emilsson, H. (2015). A National Turn of local integration policy: Multi-level governance dynamics in Denmark and Sweden. Comparative Migration Studies, 3(1), 1.

Emilsson, H. (2016). Paper planes: Labour migration, integration policy and the state (Phd). Malmö University.

Feltenius, D. (2015). Multi-level governance as "post-constitutional" politics: Subnational actors and the Swedish constitution. Local Government Studies, 41(2), 301-319. https://doi.org/10.1080/03003930.2014.919267.

Filindra, A., \& Goodman, S. W. (2019). Studying public policy through immigration policy: Advances in theory and measurement. Policy Studies Journal, 47(3), 498-516. https://doi.org/10.1111/psj.12358.

Gebhardt, D. (2016). When the state takes over: Civic integration programmes and the role of cities in immigrant integration. Journal of Ethnic and Migration Studies, 42(5), 742-758. https://doi.org/10.1080/1369183X.2015.11111132.

Goodman, S. W. (2010). Integration requirements for Integration's sake? Identifying, Categorising and comparing civic integration policies. Journal of Ethnic and Migration Studies, 36(5), 753-772.10.1080/13691831003764300. https://doi.org/1 $0.1080 / 13691831003764300$.

Hagelund, A., \& Kavli, H. (2009). If work is out of sight. Activation and citizenship for new refugees. Journal of European Social Policy, 19(3), 259-270. https://doi.org/10.1177/0958928709104741.

Hansen, P. (2018). Asylum or austerity? The 'refugee crisis' and the Keynesian interlude. European Political Science, 17(1), 128139. https://doi.org/10.1057/s41304-017-0122-y.

Hanssen, G. S., \& Helgesen, M. K. (2011). Multi-level governance in Norway: Universalism in elderly and mental health care services. International Journal of Sociology and Social Policy, 31(3/4), 160-172. https://doi.org/10.1108/01443331111120609.

Hernes, V. (2017). Central coercion or local autonomy? A comparative analysis of policy instrument choice in refugee settlement policies. Local Government Studies, 43(5), 798-819. https://doi.org/10.1080/03003930.2017.1342627.

Hernes, V. (2018). Cross-national convergence in times of crisis? Integration policies before, during and after the refugee crisis. West European Politics, 41(6), 1305-1329. https://doi.org/10.1080/01402382.2018.1429748.

Hernes, V., Arendt, J., Andersson Joona, P., \& Tronstad, K. (2020). Rapid or long-term employment? A Scandinavian comparative study of refugee integration policies and employment outcomes. Journal of European Public Policy, 1-21. https://doi.org/10.1080/13501763.2020.1824011.

Jørgensen, M. B. (2012). The diverging logics of integration policy making at national and city level. International Migration Review, 46(1), 244-278. https://doi.org/10.1111/j.1747-7379.2012.00886.x.

Jørgensen, M. B. (2014). Decentralising immigrant integration: Denmark's mainstreaming initiatives in employment, education, and social affairs Migration Policy Institute.

Kjellberg, F. (1995). The changing values of local government. Annals of the American Academy of Social Sciences, 540(1), 4050. https://doi.org/10.1177/0002716295540000004.

Kunnskapsdepartementet. (2020). Prop. 89 L (2019-2020) Lov om integrering gjennom opplæring, utdanning og arbeid (integreringsloven)

Ladner, A., Keuffer, N., \& Baldersheim, H. (2016). Measuring local autonomy in 39 countries (1990-2014). Regional \& Federal Studies, 26(3), 321-357. https://doi.org/10.1080/13597566.2016.1214911.

Ladner, A., Keuffer, N., Baldersheim, H., Hlepas, N., Swianiewicz, P., Steyvers, K., \& Navarro, C. (2019). Patterns of local autonomy in Europe. Springer. https://doi.org/10.1007/978-3-319-95642-8.

Lillegård, M., \& Seiersted, A. (2013). Introduksjonsordningen i kommunene. En sammenligning av kommunenes resultater. Statistics Norway. Report 55/2013. 
Mahnig, H. (2004). The politics of minority-majority relations: How immigrant policies developed in Paris, Berlin and Zurich. In Citizenship in European cities. Immigrants, local politics and integration policies, (pp. 17-37).

Nilsen, B. C. (2013). Introduksjonsloven. En fremstilling og vurdering av hovedreglene. (master thesis). University of Oslo.

NOU 2001: 22. Fra bruker til borger, om de funksjonshemmedes barrierer for integrering i samfunnslivet. Oslo: Sosial- og helsedepartementet.

NOU (2005). 6. Samspill og tillit- Om staten og lokaldemokratiet. Kommunal- og regionaldepartementet.

NOU (2017). 2 (2017) Integrasjon og tillit — Langsiktige konsekvenser av høy innvandring. Justis- og beredskapsdepartementet.

Penninx, R., Kraal, K., Martiniello, M., \& Vertovec, S. (2017). Citizenship in European cities: Immigrants, local politics and integration policies. Routledge.

Poppelaars, C., \& Scholten, P. (2008). Two worlds apart: The divergence of national and local immigrant integration policies in the Netherlands. Administration and Society, 40(4), 335-357. https://doi.org/10.1177/0095399708317172.

Riksrevisjonen (2019). Undersøkelse av myndighetenes arbeid med å integrere innvandrere gjennom kvalifisering og arbeid. Dokument, 3, 4 (2019-2020).

Scarpa, S., \& Schierup, C.-U. (2018). Who undermines the welfare state? Austerity-dogmatism and the U-turn in Swedish asylum policy. Social Inclusion, 6(1), 199-207. https://doi.org/10.17645/si.v6i1.1285.

Schiller, M., et al. (2020). Vielfalt and diversité: How local actors in France and Germany evaluate immigration and sociocultural heterogeneity. Comparative Migration Studies, 8(1), 1-17.

Glick-Schiller, N., \& Çağlar, A. (2009). Towards a comparative theory of locality in migration studies: Migrant incorporation and city scale. Journal of Ethnic and Migration Studies, 35(2), 177-202. https://doi.org/10.1080/13691830802586179.

Scholten, P. (2013). The multilevel governance of migrant integration: A multilevel governance perspective on Dutch migrant integration policies. The discourses and politics of migration in Europe, (pp. 151-169). Springer.

Sellers, J. M., \& Lidström, A. (2007). Decentralization, local government, and the welfare state. Governance, 20(4), 609-632. https://doi.org/10.1111/j.1468-0491.2007.00374.x.

Tronstad, K. R., \& Hernes, V. (2017). Integrering av flyktninger. In J. Askim, K. Kolltveit, \& P. G. Røe (Eds.), Smartere styring. Universitetsforlaget.

Zapata-Barrero, R., Caponio, T., \& Scholten, P. (2017). Theorizing the "local turn" in a multi-level governance framework of analysis: A case study in immigrant policies. International Review of Administrative Sciences, 83(2), 241-246. https://doi. org/10.1177/0020852316688426.

\section{Publisher's Note}

Springer Nature remains neutral with regard to jurisdictional claims in published maps and institutional affiliations.

\section{Submit your manuscript to a SpringerOpen ${ }^{\circ}$ journal and benefit from:}

- Convenient online submission

- Rigorous peer review

- Open access: articles freely available online

- High visibility within the field

- Retaining the copyright to your article

Submit your next manuscript at $\boldsymbol{\sim}$ springeropen.com 